\title{
Wordliness and the Secularization of Contemporary Nigerian Gospel Music: Implications for Censorship and Consumption
}

\author{
Endong, Floribert Patrick Calvain
}

Department of Theatre and Media Studies, University of Calabar

\begin{abstract}
Over years, it has been difficult for the Church in Nigeria to totally be unaffected and uncorrupted by the world. In tandem with this, secularism - in multiple forms - has crept into and been firmly entrenched in the church, thanks partly to the ingenious or careless attitudes of many church leaders. This secularism is reflected not only in the conduct of some important churches' affairs and spiritual programs; but equally in most communications (including gospel music) by Nigeria based religious bodies or Christians. This paper identifies the importation of (questionable) traditions - such as worldly rhythms, materialism, the avid search for fame and earthly glories as well as other controversially aggressive musical cultures - as the major indexes of secularism in the Nigerian gospel music. It argues that these phenomena somehow indicate that contemporary Christianity in Nigeria is no longer sufficiently equipped to fruitfully function as a credible censorial force. The Church has intrinsically - though inadvertently - facilitated spiritual bareness by lending support to impure music enterprises in the form of consumption, promotion and mass distribution of contaminated gospel music. The paper recommends that true Christians seek to be spiritually equipped with the TRUE Holy Spirit to be able to effectively discern and sort secularism from spirituality in gospel music; and regulate their consumption of the genre. This argument/recommendation is based on the biblical illumination that spirituality is spiritually discerned and not apprehended through human philosophical constructions and subjective reasoning as most observers seem to believe.
\end{abstract}

Keywords: Worldliness, Secularism, Gospel Music, Religiosity, Spirituality, Alternative Music.

\section{INTRODUCTION}

Gingered by a wide range of divine injunctions ${ }^{1}$, the living Church has systematically been antithetical to worldliness and secularism. In line with this, early Christianity devoted tremendous energy to distinguish and separate the spiritual from the carnal, the sacred from the secular and the world from the church, in a bid to check issues of profanity and worldliness in the church. Accordingly, any form of worldliness - be it ideological impurity, linguistic purience or cultural perversion - was considered "the enemy" and was rigorously combated, with an arsenal which went beyond mere criticism and non-conformism (to the world). As succinctly remarked by Harver (cited by Wiersbe [1988, 23]), "we [practicing Christians] are not going to move this world by criticism of it nor conformity to it, but by the combustion within its lives ignited by the Spirit of God".

However, contemporary Christianity seems to have totally weakened its defense mechanism against various forms of spiritual impurities to the extent that a multifaceted paganism is now the order of the day in many Christian denominations (Sherman 2013, 3; Robin 2015; Phil 2005). The phenomenon is even exacerbated by the fact that some evangelicals do not even - or do no longer - consider worldliness as a (grave) sin. Weerstra (1999) opines that through the instrumentality of westernization and syncretism, worldliness has successfully made its way into the Church. According to him, syncretism - the mixture of essential Christian biblical beliefs with assumptions and practices that are incompatible with the logic and principles of the faith - has resulted in the "fabrication" or "concoction" of what he refers to as "something else - [which] is no longer Christianity" (Weestra 1999, 130). In effect, western Christianity has, over the years, been profoundly syncresized through

1 Biblical verses such as Romans 12:2-3, 1 John 4:3-6, 1John 2:2:15-17 among others expressively warn Christians about the dangers of worldliness, exhorting them to flee it. 
the agency of such complex phenomena as church leaders' compromise on homosexuality and the LGBT right philosophy, Christian denominations' tolerance of rationalism, secularism and gross materialism among other vectors of worldliness. Weerstra further contends that "the Gospel in the West, including the Christian way of life, needs to be de-westernized of its non-Christian elements (of paganism disguised in modern dress and other forms of worldliness) plus we [Western Christians] need to recover (re-discover) its essence" (Weerstra 1999, 130). Such a spiritual revival is, of course, equally needed to "redress" Christianity in Africa in general and Nigeria in particular. As Aramide and Ejikeme $(2014,26)$ insightfully put it, secularism has crept into today's Nigerian church. The phenomenon has been exasperated by the various ingenious steps employed over the years by church leaders "to imbibe and entrench secular ways into the main-stream activities in God's house". In effect, the morally decadent Nigerian society has literally possessed the Nigerian church and the latter is just an exact image of the former. In furtherance of questionable ideals such as materialism and greed, churches have resorted to commercialism and adopted the mercantilist air of the Coca-cola or Nestle Company instead of the humanity of the Red Cross. Through the prosperity theology, an impressive number of church leaders and Christian vitalities have exhorted and successfully indoctrinated their congregations to anchor their faith principally, nay exclusively, on material possessions. Poverty is openly branded a curse according to the theology propagated by numerous churches. In line with this, church designers and neo-Christian apostles have proffered all embracing liturgies and doctrines devoid of pungency to accommodate the rich - who will not want to be embarrassed - as well as sympathizers with liberal minds. A lot is therefore to be revised and thoroughly revamped in the House of the Lord.

Postmodern fashion style (provocative dress style), compromise by church leaders on the LGBT right philosophy and materialism (as noted above) certainly do not constitute the exhaustive list of vectors and facets of worldliness or paganism in modern Christianity. Scholars and Christian observers such as Robin (2015), Endong (2015), Awake (2013) among others hold music - especially "contaminated" and secularized gospel music - partially responsible for the progressive rise and prevalence of worldliness and other impure cultures or traditions in the Church. Robin succinctly underlines this fact in his comparison of the early church with contemporary Christianity. He contends that:

[...] The early church lived in a world where the line between Christianity and paganism was very real, very distinct and very palpable. One of the chief areas where the tentacles of paganism were most strongly felt was in popular music.

Paganism still makes inroads into the church through music, though sadly many Christians no longer believe music is an area where we need to exercise discernment. They have fallen prey to a number of music myths perpetuated by the godless philosophy of our day. (Robin 2015, 23)

In the same line of argument and with particular reference to Nigeria, FDD quoted by Servant (2003, 67) underscores the duality of music (how it can serve two opposite purposes) and how it has over the year become a powerful "satanic" weapon through which numerous gospel music cultures/traditions and spirituality have been eroded in the Nigerian religious music ecology. He contends that "the Bible said he [Satan] comes steal and destroys. The devil is looking for whom to seek and defy. He is coming through music, because music penetrates more than anything". In effect, the incorporation of visibly worldly musical traditions in the Nigerian gospel music has had seriously deleterious effects on the credibility of particular artists (megastars) and even of some churches (or religious leaders) that support such a contentious musical enterprise, at least through consumption and promotion.

The above mentioned worries (by Robin, 2015 and Servant 2003) are more than pertinent if one considers the progressive/increasing secularization of the Nigerian gospel music characterized by the imitation of secular musical traditions (in both music composition and performance), the integration of purely secular music performance or performers into spiritual programs (such as crusades), pagan musicians' successful entrance into the gospel music industry among a wide range of other indexes. This paper examines in details the complex nature of this secularization, comparing it with similar movements in other climes and discussing its implications for gospel music censorship in Nigeria. 


\section{THEORETICAL FRAMEWORK}

This paper is anchored on the Unique Master Theory, inspired by Luke $16: 13^{2}$, which underscores the impossibility for a servant to simultaneously serve two (opposing) masters. Based on this biblical analogy, the Unique Master Theory considers the Christian in general and the gospel singer in particular as a servant working exclusively for God (his Creator). Christian music is, in this respect, construed as a (singing) ministry and the gospel singer, a minister who must exclusively serve God to win the Latter's grace as well as the recognition and acclaims of the Christian community. Being a "minister of God", the gospel artiste is compelled to "do something different in a way that God's name will be glorified" though the general trend is for most people to prefer worldly musical traditions. The gospel artiste is also called upon "to live up to standard" (Araybanye cited by The Ogun State Television, 2014). According to the Unique Master Theory, any deliberate mixture of worldly traditions with genuine gospel music cultures is to be read as an attempt at dual loyalty (to God and Satan). Such a mixture can only lead to adulteration of gospel music and consequently a "bad sacrifice". In an interview granted the Nigerian tabloid Newswatch Times, gospel artiste Ayansina Adefolawe makes an alarming diagnostic of the Nigerian gospel music industry where she underscores the above mentioned aspect of this theory: "God said we cannot serve two masters. Our message has been contaminated. You'll even see a so called gospel artiste changing secular lyrics to a church song just to get people dancing. What we do now is mere entertainer I will say 40 percent of us are guilty of this". Ayansina further points at the deviational character of Nigerian gospel music when she notes that: "We have shifted our eyes from the one who called us and are now chasing after money" (Quoted by Dayo, 2014, 19).

The Unique Master Theory strictly differentiates service to the world (often considered as service to carnality and to an extreme extent, service to the devil) from service rendered to/for God. In line with this, secular musicians are considered to be exclusively serving the world and not God. Gospel artiste Samsong (quoted by Chimezie 2015) succinctly underscores this point in his observation that: "when a secular musician is on stage entertaining, it is not about God. That is the difference between gospel musicians and their secular counterparts" (Chimezie, 2015). It should however be noted that statements of this nature are clearly declarative, sentimental and somehow one-sided. The onesidedness of such a statement is revealed by the fact that one cannot scientifically understand the basic motivation of secular musicians. One may hardly tell the genuineness of a secular musician not recognizing the role of God in his life. It is undeniable that some of these secular artistes actually pass "sincere" messages about how God has blessed them. It should equally be envisaged that a majority of Nigerian Gospel Musicians - including Samsong quoted above - sing 'to make a living' and thus use God's name to make money just like their counterparts which are popularly or pejoratively branded secular.

Nevertheless, according to the Unique Master Theory, the secular musicians are diametrically different from gospel singers. While the former set of musicians are mere entertainers, the latter set are valuable instruments God flexibly uses for His glory, ministering unto people and saving their lives for paradise. In this wise, while secular musicians mainly seek to satisfy the carnal urges of their audiences (that is those who consume of their music), gospel musicians connect their listeners to God through profound and complex spiritual energizing. Gospel singer Busayo Odutayo (quoted in Ekpo 2015) stresses this point when he remarks that:

Every other kind of music, except gospel, focuses on making the listeners to dance. There is very little emphasis on message. But gospel music is not like that. Ideally when people, especially worldly people, listen to real gospel music, they should feel a strong urge to turn away from sin. If the music is right, it should inspire them to question the way they have been living. Only gospel music has the power to ignite such feelings and this is what makes it different from other styles.

\footnotetext{
${ }^{2}$ In Luke 16:13, the Lord Jesus exhorts saying "No servant can serve two masters: for either he will hate the one, and love the other; or else he will hold to the one, and despise the other. Ye cannot serve God and mammon".
} 
In the same line of argument, Samsong quoted by Chimezie explains that "the gospel is the good news. In the same vein, the gospel artiste is the propagator of the good news. More than the physical, gospel music is about the spiritual. In the midst of the singing and dancing, there must be the move to recognize the presence of God". By stressing on the impossibility to serve the world and God (with respect to music making), the Unique Master Theory castigates the tendency by (mainly nominal) Christians to indulge in - or even simply consume - secular music. By this principle, the Christian artiste should stay clear of secular music. Proponents of the theory, believe that a Christian musician is "God's exclusive propriety and vessel"3. This tenet is backed by biblical verses indicating that God does not share his glory with adversary forces (the world). However, a number of schools of thought have sought to deconstruct this particular keystone of the theory, arguing that it is problematic and thus unfair to limit the application of the unique master principle only to music and not to other professions. Such a pertinent antithesis is given by Bonner who succinctly notes that:

There are many who make the argument that our gifts were designed to glorify God, with the suggestion that the only way to do that musically is to sing gospel or Christian based, vertical music. If that inference is indeed true, then that principle should be universal across every line of work. Every doctor should only work in Christian hospitals and serve Christian patients. Every carpenter should only construct buildings that will house the worship of God. Following this principle, believers should only purchase "Christian" products or support "Christian" ventures.

In reality, believers don't operate like this. In fact, this thought only seems to be applied to the arts. Isn't it funny that we will celebrate a believer finding success and receiving promotion on their "non-gospel" corporate job, but will lambaste the believer who sings and finds success if their "non-gospel" job is a club or record label of another genre? Well, what is the Bible's position on this? (Bonner 2014, 34)

According to such counter schools of thought, it is very possible to positively impact the life of people with humanistic lyrics and songs, fashioned according to contemporary styling of secular music. All what counts is the Christian being the light of the world as prescribed by the Bible. As further explained by Bonner, what is important is "cultural relevance to the unbeliever with the line of demarcation being the character of Christ. Christ's character has nothing to do with attire and everything to do with the attributes of Christ" (Bonner 2014). In a nutshell, whatsoever genre or musical culture a Christian chooses to adopt, what actually counts is him adopting a life up to standard and composing good lyrics that possess the capacity to positively impact the lives of consumers.

\section{REVIEW OF CONCEPTUAL Literature}

It would be expedient to begin this review by providing conceptual definitions of the two key words of the topic under discourse, namely worldliness and secularization. Worldliness could simplistically be defined as (the love of) what pertains to the world or the earth. In line with various other biblical illuminations, it is the tendency for one to set his or her affections on the things of the world rather than on heavenly or spiritual things. In the same line of thought, the Longman Dictionary of Contemporary English $(2010,271)$ envisages worldliness as the tendency of being "concerned with the ways of society, especially social advantage, not spiritual". Christians - especially fundamentalists - consider worldliness a grave sin in accordance with a multitude of scriptural references indicating that the love of the world is enmity with God (for instance James 4:4, Colossian 3:2, Romans 12:2-3; I John 2:15-17). Such a reasoning lies on the premise that the world's philosophies and value-systems are all based on principles that are spiritually antithetical to genuine faith. Worldliness is associated with excesses and syncretic practices such as materialism, - Which the Longman Dictionary of Contemporary English $(2010,670)$ defines as a "state of mind or way of life which enjoys the pleasures of the world, objects which can be bought etc. and activities of the mind or spirit, in art and

\footnotetext{
${ }^{3}$ This is by analogy with the metaphor used by the Apostle Paul in 2 Timothy 2: 20-21 which stipulates that "But in a great house there are not only vessels of gold and of silver, but also of wood and of earth, and some of honour, and some of dishonour. If a man therefore purges himself from these [spiritual impurities or sin], he shall be a vessel unto honour, and prepared unto every good work".
} 
religion" - as well as with paganism, "immoral" dress style, the adoption of human philosophy and worldly standards among others. In line with this, Kumuyi, founder and general overseer of the Deeper Life Church, equates the celebration of presumably "Christian feasts" such as Christmas and Easter to forms of worldliness. In one of his sermons, he defines Christmas as a facet of subtle idolatry and a feast with clearly worldly or pagan origins. He laments that today, we find church leaders and theologians "trying to introduce the idolatry of mystery Babylon, that they call Christmas" and "wanting to bring all the Christmas carol saying that is the day that Jesus was born"; meanwhile these practices are nowhere found or prescribed in the Acts of the Apostles or observed in the early church. These practices, according to him, were to be categorically demonized and proscribed in the church.

According to Phil, worldliness should be viewed as "a sin of the heart", which is not necessarily related to secular movies, music styles, the latest fashions, or other typical fundamentalist taboos. Though such cultural artifacts certainly can be worldly and "obviously do have a tendency to provoke sinful worldliness insofar as they naturally appeal to our passions and tempt us to become obsessed with earthly things" (Phil 2015, 17). To him, expressions of dogmatism which favor one's attachment to an earthly religious enterprise rather than genuine spiritual or divine prescriptions could also be considered a form of worldliness. He insightfully notes that even conservative, doctrinally-sound religion can be worldly too. If a person, for instance, gives less attention to heaven and heaven's values than to the trappings of "a worldly sanctuary" — be it an ornate cathedral, a megachurch with a Starbucks kiosk in the foyer, or a lowbrow church where snake-handling provides the entertainmentthat person is worldly and living in disobedience to God" (Phil 2015, 17).

Secularization on the other hand is a phenomenon which stems from the secularist doctrine. This doctrine (secularism) strongly militates against religion's involvement in the organization of the society, or ideological state apparatuses (for instance education, the law and the like). In line with this, secularization is construed as "the act or process of removing the influence or power that religion has over something" (Oxford Advanced Learner's Dictionary 2010). This paper however hinges on the Longman Dictionary's definition of the phenomenon. "Secularism" - this dictionary says - "is the quality of behaving in a way that shows religion does not influence you. It is being in the church but not in Christ. It is a life full of church activities but deeply enmeshed in carnally and sinfully. It is being nominal, lifeless and spiritually carnal" (Longman Dictionary 2009). This implies that secularism involves religiosity which is the mere belief in God and practice of some pious rituals without substantial adherence to spirituality. Spirituality, it should be noted, is "an internal process of seeking personal authenticity, genuineness, and wholeness as an aspect of identity development" (Love 2014, 5). Secularism therefore has a strong link with worldliness. In effect, it often implies the presence of (sinful) worldliness. It has been observed that it is the Church's inclination towards secularity that has often caused her to (in)adventently embrace worldliness and paganism. To respond to the challenge of secularism, most church leaders and Christian vitalities have spectacularly adapted to secular standards in terms of language, thought, and way of life, thereby subtly embracing worldliness. As Olthuis passionately notes,

One realizes that this is no light matter! For such has been the experience of the Body of Christ that when she ventured outside of the church-gates and mingled in the affairs of the market-place, she adjusted, compromised and even denied her Message; when, on the other hand, she was content to, or forced to remain within her walls, she failed to give concrete form to the Christian witness and discovered to her own consternation that she was "outside" of the world. (Olthuis 1986, 34)

Secularism is one of the most contentious phenomena igniting deep concern about the state of Christianity in contemporary Nigeria. In effect a good number of Nigerian Church leaders have designed ingenious ways of imbibing and implanting secular cultures and spiritual impurity in the activities of their churches. Egregious examples of these worldly and spiritually poisonous traditions include the conception of theologies and liturgies principally rooted in materialism, exhibitionism, the celebration of pagan feasts (which arguably have been Christianized), the endorsement of the LGBT right philosophy (seen Rev. Olajide's House of Rainbow also known as LGBTI church) among others. The inclusion of such worldly or secular traditions is made complex and somehow exacerbated by the perceived elusiveness of the concepts of worldliness, paganism and secularism. The multiple 
and often concurrent interpretations of biblical scriptures coupled with the arguable adherence to church dogmas or doctrines have caused many denominations to have varied definitions of worldliness and paganism, to the extent that the conceptualization of worldliness largely depends on personal(ized) judgments and readings of the Holy Scriptures. And as such, each denomination or Christian has its/his theory and subjective approaches to determining and combating - if not to inadvertently encourage it, - worldliness. For instance, while a number of Pentecostal churches and charismatic groups indict the celebration of Christmas, branding it a worldly and pagan/satanic tradition, most orthodox Christian vitalities observe the Christmas carol. In line with this, Kumuyi (founder of the Deeper Life Church) censures Christmas celebration thus: "We don't celebrate Christmas. It actually came from idolatrous background. That is why you don't hear us sing what they call Christmas carol, Never! [...] We are not trying to make the church turn like the world. We want it to be like Jesus Christ, and more like the Apostles. If you don't have that mind with us, then you have permission to go to other places" (cited in The Punch Newspaper 2013, 23)

In his diagnostic of Christianity in contemporary Nigeria, the Founder/President of International Church Growth Ministry, Akin (cited by Aramide, 2014) laments over the persistence and growth of worldliness in most Christian denominations in the country, associating this twin phenomenon to a series of deleterious consequences including incidences of backslidings among proselytes and spiritual barrenness in the nation. He remarks that:

In our churches today, preachers and people are behaving in amazing ways that point to the fact that they don't know God, or have totally lost the fear of God in their lives. Despite the increasing popularity of the church, spiritual impact upon the people, the society and the nation is abysmally low. In many quarters, the church, especially the Pentecostal and Charismatic expressions have become the butt of joke in the society. Many sincere people have been wounded and lots of young converts have backslided due to the untoward and ungodly practices that removed godly influence from the church.

[...] In the last 30 years, I have watched with trepidation, how churches sprang up one after the other, with secular mandates to compound the precarious position it occupies in the world. Yes! The church is popular with people in government, governors, senators, bankers and highly placed people in the society. Yet, the reality on ground is that spirituality is completely at its lowest ebb. (Cited in Aramide and Ejikeme 2014, 26)

The secularism which reigns in the Church in Nigeria is seen in the importation of such contentious practices as fashion parade, beauty pageant, suggestive dance styles during evangelical crusades or activities, worship services and the like by some Christian denominations. It is also important to note that under the guise of adhering to the prosperity gospel paradigm, a good number of churches have adopted materialist orientations, basing their sacerdotal discourses and programs on purely motivational "evangelization" which in reality has turned out to be a vector of the pursuit of materialism, fame, in short, earthly glories at the detriment of salvation. In his Rhapsody of Realities (November 2015), Chris Oyakhilome (founder and general overseer of Christ Embassy) teaches that being the "seed of Abraham", the Christian should "always have the mentality of abundance and be prosperity conscious", because God has chosen to bless the world through him or her (Chris 2015, 23). The keeping of a prosperity-conscious mind should, according to him, be irrespective of the one's social background and natural abilities. In a motivational tone, Chris further explains in his Rhapsody of Realities (October 2015) that:

When you give to the Lord, don't do so with the mentality of lack or loss; don't get in the flesh by "calculating" what's left over [...] That's not Kingdom consciousness! Such mentality could hinder your harvest. You should rather ask yourself, "what's the promise on [what] I'm about to give. You could have a thirty-fold return, a sixty-fold return, or a hundred-fold return! So, what you should be thinking about is the harvest. [...] That way, you set into motion the miracle-working power of God for a great harvest. It's a mentality; train yourself in it. (Chris 2015, 13) 
Bishop Josef Bassey of the God's Heritage Global Mission similarly teaches his congregations to be prosperity conscious with his expository discourse on the "near miracle syndrome" and how to surmount it. In his publication titled Miracle Wings, he teaches that "if you are a victim of [the] near miracle syndrome, $[\ldots]$ there are powers fighting against your harvest $[\ldots]$ The good news is that it doesn't matter what has been opposing your harvest, every power can be crushed" (Bassey 2015, 1). Prosperity theologians tend to motivate their congregations to be more prosperity conscious and materialist than spirituality-conscious. With this, most congregations are spurred to primordially nay exclusively seek "cheap" material and health blessings. This has caused secularism to prevail in an impressive number of Christian vitalities. Such secularism is also reflected in a good number of Christian communications (religious magazines, newspaper, television programs) including gospel music. Material and health prosperity is for instance the dominant themes of most Christian communications. As shall be discussed in the following section of this paper, most Nigerian gospel artistes seem more inclined to the prosperity gospel paradigm as most of their songs are vehicles of prosperity messages. Popular Nigerian gospel artists such as evangelist Ebenezer Obey and Frank Edwards have, for instance made material and health prosperity a dominant theme of their musical compositions. To some observers, the presence of secularism in the gospel music vividly translates the failure of religious leaders, or churches in combating worldliness; given the fact that the artisans of such syncretized musical or artistic traditions are the products of churches. Such artisans often time receive direct or indirect support from Church institutions or leaders in the form of consumption, honorarium (after performance in church spiritual programs) and promotion (Osaremen 2015; Ezeh 2014; Gordon 2014). As shall be discussed in the subsequent sections of this paper, the Church in Nigeria seems no longer to effectively play its censorial function. It seems to have totally lost its spiritual equipments to influence and control the gospel music industry, for a genuine and impactful artistic production.

\section{SeCularism in the Nigerian Gospel Music}

The Nigerian gospel music is both a vector and a mirror of secularism prevailing in the Church in Nigeria. One of the multiple aspects of secularism in the Nigerian gospel music industry is the importation of (hitherto) demonized and harmful musical cultures, including rock and roll, hard rock, gangster rap, raga Murphy, Rap and Beat (R\&B) among others. Popular Nigerian gospel artistes such as Frank Edwards, Sinach, Bukola Folayan (a.k.a. Bouqui), Buchi, Ada, and Samsong are noted for their choice of Rap, R\&B and hard rock as rhythms of predilection. Similarly, gospel artiste Lara George has been incorporating the rapping mode into a number of her musical compositions. The adoption of such controversial musical traditions largely rests on the popularization of philosophies such as liberalism and subjectivism which want that modern and urban music styles be reconsidered and tolerated as they may be working baits to "fish men" for the Kingdom of God, especially the youths who are ardent consumers of such musical cultures. By so doing, most pro-worldly rhythms seek to deconstruct popular conceptions, and labeling/branding of aggressive urban music. However it is important to discern that some musical traditions contain, in themselves, negative spiritual charges or entities that are inconvertible - sometimes generated by their origin and evolution - which makes them inherently harmful and inappropriate for offering sacrifice to God. Some actually have connotations that, to us, are hardly or impossible to be deconstructed. An egregious example is the Rock and Roll rhythm which is actually a metaphor for an illicit sexual act. According to Yusko and Prior (2014), the term means "fornication". The necessity and imperative of wining souls through strategic methods should not however discard the fact that God cherishes holiness and evangelic strategies or tools that are worthy of praise. Yusko and Prior (2014) pertinently underscore this fact when they note that:

We are told by the religious rockers that we must look and sound like the world in order to reach the youth of this generation. They say, many young people will not listen to the gospel or come to church so we must meet them on some common ground. That common ground is rock and roll. In other words, they are saying that preaching of the Word of God is no longer sufficient for both young and old. If this is true, then we should open bars in order to reach the multitudes of drinkers. We should open porno-shops in order to reach those who engage in smut. Shouldn't we go to their level so we can bring them to the Lord Jesus Christ? So what if 
we do evil if the end result is good? What's a little compromise with God's standards of holiness and separation if it results in souls being saved? [...] This type of reasoning is one of the doctrines of demons that Christians are accepting. Does it not make sense that the same Bible that has worked successfully to this time, will continue to work for both the young and the old?

Apart from adopting controversial rhythms, many Nigerian gospel artistes are also fond of imitating secular musicians' composition and performance styles. In some instances, the artistes struggle to be perfect replicas of secular artistes with respect to voice, dress mode, walk. talk and dance styles and one is left to wander what all these marginal efforts have to do with praising God and winning souls to the Lord (Eze 2014; Osaremen 2014). While Frank Edwards often adopts rapping styles which could be likened to those of Pitbull (a famous secular American rapper), Bouqui often copies the style of Ashionye - an unrepentant secular rapper and dancer who features her (Bouqui) in his Party Tonite. Also worth noting here is the production of remix versions of popular secular songs, where original instrumentation (melody) is maintained and religious messages are injected in the lyrics in an attempt to appeal both to the pagan community and the Christians. Popularly called the "gospelization" or appropriation of secular music, this practice is a good illustration of attempts at serving the world and God simultaneously. The practice is common among gospel singers who are motivated by the desire to achieve commercial success, prioritizing fame, money, earthly glories to preaching the gospel and praising God. The Rooftop MCs (a group of gospel singers) could be cited as an egregious example to illustrate our position. The Rootfot MCs are noted for their talent in mixing secular and seemingly gospel musical traditions. Their lyrics seem to draw from the Scriptures. However, to benefit from the economic largesse entitled to secular artistes, they are prompt to deny that they are gospel music makers. In her appraisal of the Nigerian gospel music, gospel singer Ayansina (cited by Dayo 2014, 34) denounces such a capitalistic culture, emphasizing that the evangelical message of the gospel music enterprise in Nigeria has been contaminated and its salvific purpose subtly frustrated. "You'll even see a so called gospel artiste changing secular lyrics to a church song just to get people dancing. What we do now is mere entertainment. I will say 40 percent of us are guilty of this. We have shifted our eyes from the one who called us and are now chasing after money" (Cited in Dayo 2014). Ayansina further notes that the phenomenon is exacerbated by the popular belief among gospel musicians that "there seems to be more money in secular music than gospel and some gospel artistes want to get rich quick" (Cited in Dayo 2014).

The problem with remix versions of secular songs is that, besides indicating the materialistic inclinations of gospel singers it gives the faulty impression that God - the inspiration source of any genuine religious enterprise - is incapable of inspiring both the lyrics and the melody of the songs. Another evidence of secularism in the Nigerian gospel music industry is the tendency to produce songs in which feature secular musicians. This is visible in the artistic production of gospel singers such as Kefee (featuring Timaya), Kenny Saint Best (featuring G, Dargin), Lara George (featuring Lord of Ajasa) ${ }^{4}$ among others. All this translate adherence to a capitalistic orientation, the search for economic breakthrough (somehow at the detriment of pure evangelic objectives). Another notable phenomenon is that of secular musicians who, under the guise of thanking God or "evangelizing", make religious songs be part of their albums. A good example is Korede Bello's Godwin which categorization as Christian song has been subject to profound controversy. The practice of religious songs by secular Nigerian artiste could likewise clearly be interpreted as a commercial strategy. Given the fact that there is serious competition in the secular music industry, this strategy offers musicians the possibility to appeal to the Christian community and thereby sell their musical production to a larger fan base.

\section{IMPLiCATIONS FOR GOSPEL MUSIC CENSORSHIP IN NigERIA}

Christianity used to be a strong sensorial force in the Nigerian music and cultural industry in general. Such a central position has sometimes even "annoyed" secular music makers who often found themselves unduly "condemned" to self-censorship and alignment to Christian values to hope to thrive in the music business. Dagga cited in Servant $(2003,67)$ corroborates this fact thus:

\footnotetext{
${ }^{4}$ Timaya, Dargin and Lord of Ajasa are popular Nigerian Hip-Hop singers. They are all secular musicians.
} 
The Islamic ideas in the [Nigerian] music industry are not as strong as the Christian ideas, and this is something which is neglected in the question of who controls the music industry. It is clear: big businesses control that industry and those people have a tendency towards Christianity. [...] So to finally resolve the question of religion, it's something that protest artists should get more involved [...] More thing need to be done in that part to help people clarify the role of religion in their lives $[\ldots]$ These conservative forces have to be taken up. (Servant 2003, 67)

However, with the recrudescence of secularism in the Nigerian gospel music, it becomes increasingly evident that the Church institutions are losing their spiritual energy and dexterity to effectively function as valuable and consequential sensorial forces, with respect to music - especially gospel music production in the country. As Yusko and Prior (2014) insightfully contend, "the fact that demonic music even made it into the church is proof of the moral and spiritual decline affecting the church today". The various Church institutions or Christian denominations are rather intrinsic accomplices of a cultural perversion, as utterly worldly songs punctuated with religious messages are produced, promoted and mass distributed with their blessing and cooperation. In view of this, the true Christian (Spiritual man) is more than ever called unto more vigilance for a healthy consumption of gospel music. In effect, from a spiritual point of view, not all so-branded Nigerian gospel songs qualify for consumption by a true and spiritual Christian aiming at sincere and methodic praise and worship. As has been alluded to, rare are the Nigerian gospel songs possessing the potential to actually connect a listener/consumer to God. A good number of them lack the spiritual energy to facilitate a fruitful spiritual intercourse with God; and so, they only make you dance and sing just for dancing and singing sake.

It therefore becomes important for each consumer/listener to be equipped with relevant spiritual tools (the TRUE Holy Spirit) needed to detect/discern and sort spiritual gospel from syncretized and spiritually poisonous music. As has clearly been emphasized by the Bible, "the things of the Spirit of God (spirituality) are spiritually discerned" (1 Corinthians 2:14) and such a power to discern is exclusively reserved to true Children of God. This is made clearer by the fact that the Holy Spirit (gift of God to all true Christians ${ }^{5}$ ) is a faithful and reliable guide and teacher (John 14:25-26).

The varied, concurrent, personalized and relatively unreliable definitions of worldliness persist - and tend to continually encourage secularism in the Nigerian gospel music - because most religious observers seem to hinge on human constructions of the subject and subjective reasoning. It is obvious that if we were all "possessed" by the same TRUE Holy Spirit in our understanding of the phenomenon, be it gospel musician or gospel music consumer will be similar. We will unanimously discern and know what is secularism in gospel music and what is not. And with such a unanimous view of the phenomenon, we will know the relevant music culture to encourage in and for the Church.

\section{CONCLuSion}

This paper has examined the phenomenon of secularism in the Church in Nigeria, characterized by the importation of a wide range of deleterious cultural practices which both evidence and intensify spiritual blindness and bareness in the House of God. The paper identified fashion, dancing style, contaminated or syncretized gospel music among other vectors of secularism prevailing in many churches based in Nigeria.

The paper equally analyzed the phenomenon of secularism in the Nigerian gospel Industry. It identified the importation of questionable worldly rhythms, materialism, the avid search for fame and earthly glories as well as other controversially aggressive musical cultures, as the major indexes of secularism in the Nigerian gospel music. It argues that these phenomena are proofs that contemporary Christianity in Nigeria is hardly sufficiently equipped to fruitfully function as a credible censorial

\footnotetext{
${ }^{5}$ In John 14:16-17, the Bible presents the Holy Spirit as a divine gift which cannot be obtained by the "world" (unbelievers). Here Jesus refers to the Holy Spirit as "the Spirit of truth who the world cannot receive, because it neither sees Him nor knows Him".
} 
force as it used to be. The Church has intrinsically facilitated spiritual bareness by lending support to impure music enterprises in the form of consumption, promotion and mass distribution of contaminated gospel music. The paper recommends that true Christians seek to be spiritually equipped with the TRUE Holy Spirit be able to effectively discern secularism in gospel music and regulate their consumption of the genre. This argument and recommendation is based on the biblical illumination that spirituality is spiritually discerned and not through human philosophical constructions and reasoning.

\section{REFERENCES}

[1] Agoro, Saviour N. 2015. Further Themes in Christian Drama in Nigeria. EJOTMAS: Ekpoma Journal of Theatre and Media Arts, 5(3), 55-67.

[2] Ajiri, Efeturi. 2013. Impactful Singing. Port Harcourt: A-Jayz Prime Music.

[3] Amadi, Elechi. 2005. Ethics of Nigerian Culture. Ibadan: Heinemann Educational Books.

[4] Aramide Oikelome \& Ejikeme, Omenazu. 2014. Why Secularism Thrives in Church. Daily Independent, No. 36, 26-27.

[5] Ashbaugh, Juliane E. 2012. "Christian Music Industry and Church Music: The Relationship Between Christian Music Industry and Church Worship Music". Available [online] at http://www.ashbaugh/articles/christian_music_industry_and_church_music.com Acessed on the 27/06/2015.

[6] Bassey, Josef. 2015. Miracle Wings. Calabar: God's Heritage Global Mission.

[7] Bauder, Kevin T. 2015. "Theories of Inspiration". Religious Affections. Available [online] http://www.religiousaffections.org/articles/in-the-nick-of-time/theories-of-inspiration. Accessed on $25 / 06 / 2015$.

[8] Bonner, Gerard. 2014. Secular Vs. Gospel - The Next Chapter. Gospel Flava.Com Magazine, Available [online] at http://www.secular-vs-gospel-the-next-chapter/gospel-flava.com Accessed on the 22/08/2015.

[9] Burgess, Richard. 2008. Freedom from the Past and Faith for the Future: Nigerian Pentecostal Theology in Global Perspective. PentecoStudies, 7(2), 29-63.

[10] Calhoun, Craig. 2010. Rethinking Secularism. The Hedgehog Review, 12(3), 35-48.

[11] Chimezie, Ijezie. 2015. Should a Gospel Artist go Secular? Available [online] at http://chimezieijezie.blogspot.com/2015/04/should-gospel-artiste-go-secular.html Accessed on the $24 / 08 / 2015$.

[12] Chris, Oyakhilome. 2015. Rhapsody of Realities (November 2015). Lagos: Christ Embassy.

[13] Chris, Oyakhilome. 2015. Rhapsody of Realities (October 2015), Lagos: Christ Embassy.

[14] Cloud, David. 2014. The Transformational Power of Contemporary Praise Music. Port Huron: Way of Life Literature.

[15] Crowe, Barbara J. 2010. Music and Soulmaking: Toward a New Theory of Music Therapy: New York: Sacrecrow Press.

[16] Dayo, Emmanuel. 2014. Some Gospel Artistes Now Use Secular Lyrics for Upbeat. Newswatch Times, No 11, 19.

[17] Durkhein, Emile. 2008. The Elementary Forms of Religious Life. New York: Oxford University Press.

[18] Ekanem, S. A. \& Bassey, P. A. 2009. "Religion and Science as Tools of Economic and Social Development”. ONIONG: A Contemporary Journal of Inter-Discipline Studies, 1(1), 1327.

[19] Ekpo, Nathan Nathaniel. 2014. Gospel Music Ignites Feelings Unlike Secular Music Songs Bussy Crown. Nigeria Film Com. Available [online] at http://www.gospel-music- ignitesfeelings-unline-secular-music-songs/nigeria-film.com Accessed on the 21/08/2015.

[20] Endong, Floribert, P. C. 2015. "Glossolalia in the Nigerian Gospel Music: Aesthetic Feature or Archetype of a Pentecostal Identity?". IJAHS: International Journal of Art and Humanity Sciences, 2(2): 14-20. 
[21] Etcetera. 2014. "Nigerian Gospel Artistes are Hypocrite". GistMannia, Available [online] at http://www.gistmannia.com. Accessed on the 17/06/2015.

[22] Ezeh, Emmanuel. 2014. "Opinion: In the name of Gospel Music". Available [online] at http://www.naij.com/67712.html. Accessed on the 16/06/2015.

[23] Frith, S. 1996. Performing Rites: On the Value of Popular Music. Cambridge: Harvard University Press.

[24] Gordon, David T. 2014. "The Imminent Decline of Contemporary Worship Music: Eight Reasons". Second Nature Journal. Available at [online], http://www.secondnature.com/theimminent-decline-of-contemporary-worship-music-eight-reason/htm. Accessed on 26/06/2015.

[25] Hurd, Shakman E. 2004. The Political Authority of Secularism in International Relations. EJIR: European Journal of International Relations, 10(2), 235-262.

[26] Joseph, M. 1999. The Rock and Roll Rebellion. Nashville, Tennessee: Broadman \& Holman.

[27] Lauritsen, Matthew W. 2011. "Secular Mode, Sacred Message: How Contemporary Christian Musicians are Called by God to Perform". Sociology Undergraduate Research Paper 2, Available [online] at http://www.repository.stcloudstate.ed/soc_org_research/2 Accessed on the 27/06/2015.

[28] Love, MacArthur. 2014. "What is the Difference Between Religion and Spirituality?" Gotquestions. Available [online] at http://www.gotquestions.org/religionspirituality.html\# rxzz3d3eboWFb. Accessed on the 16/06/2015.

[29] Maduka, Chidi T. 2003. "The Clouds are Thickening: Nigerian Languages and Literatures in National Development". JONEL: Journal of Nigerian English and Literature, 4(1): 11-19.

[30] Meyer, Brigit. 2003. "Pentecostalism, Prosperity, and Popular Cinema in Ghana". Representing Religion in World Cinema: Film Making, Mythmaking, Culture Making. New York: palgrave MacMillan.

[31] Offiong, Ani O. 2005. "Video-Films as Mediators of Pentecostal Christianity in Nigeria: A Case Study of Liberty Video-Films". WAACLALS: West African Association for Commonwealth Literature and Language Studies, 2(1), 106-119.

[32] Ogun State Television. 2015. Gospel Singers Now Copy Secular Artistes - Araybanye. Ogun State Television, Avaialable [online] at http://www.gospel-singers-now-copy-secular artiste/ogun-state-televion.htm. Accessed on 22/08/2015.

[33] Okon, Etim E. 2008. "The Sociological Imagination on Religion”. CASIL: Calabar Studies in Languages, 14(1), 110-138.

[34] Olsen, Ted 1996. "Too Holy for the World, Too Worldly for the Church". CT: Christianity Today, 40(11), 12-27.

[35] Olthuis, James H. 1986. Must the Church be Secular? New York: McGrawhill.

[36] Phil, Jhon. 2005. What is Worldliness and When is it Sinful? Pyromaniac, Available [online] at http://www.what-is-worldliness-and-when-is-it-sinfyl/pyromaniac.com Accessed on 22/08/2015.

[37] Robin, V. 2015. "Music: Myths, Meanings, Messages and Mediums". Christian Worldview Journal. Available [online] at http://www.christianworldviewjournal.com/html. Accessed on the $16 / 06 / 2015$.

[38] Servant, Jean-Christophe. 2003. Which way Nigeria? Music under Threat: A Question of Money, Morality, Self-Censorship and the Sharia. Denmark: Freemuse.

[39] Stouffer, Georges. 2012. Evaluating Music Biblically- A Concise Guide. New York: International Partnership Ministries Inc.

[40] The Holy Bible. 2007. Authorized King James Version. Chicago: Remnant Publications.

[41] Ukpabio, Helen. 2007. Rapture. Oweri/Lagos: Liberty Films.

[42] Ukpabio, Helen. 2008. The Seat of Satan Exposed. Calabar: Liberty press. 
[43] Wayne, Jackson. 2014. "The Divine Pattern of Acceptance Worship". Christian Courier Publication. Available [online] at http://www.christiancourierpublication.com Accessed on the $17 / 06 / 2015$.

[44] Wiersbe, Warren W. 1988. Be Dynamic, Wheaton: Victor Books.

Citation: Endong, Floribert Patrick Calvain. "Wordliness and the Secularization of Contemporary Nigerian Gospel Music: Implications for Censorship and Consumption." International Journal of Research in Sociology and Anthropology (IJRSA), vol 3, no. 3, 2017, pp. 32-43. doi:http://dx.doi.org/10.20431/24548677.0303004.

Copyright: () 2017 Authors. This is an open-access article distributed under the terms of the Creative Commons Attribution License, which permits unrestricted use, distribution, and reproduction in any medium, provided the original author and source are credited. 